Mеталлофиз. новейшие технол. / Metallofiz. Noveishie Tekhnol. (C) 2016 ИМФ (Институт металлофизики 2016, т. 38, № 7, сc. 935-952 / DOI: 10.15407/mfint.38.07.0935 им. Г. В. Курдюмова НАН Украины) Оттиски доступны непосредственно от издателя

Фотокопирование разрешено только

Напечатано в Украине.

в соответствии с лицензией

PACS numbers: 61.72.S-, 62.20.fk, 62.20.M-, 81.05.Bx, 81.40.Cd, 81.40.Ef, 81.40.Np

\title{
Influence of Phase Composition and Microstructure on Mechanical Behaviour of the Metastable Ti-3Al-4.5Fe-7.2Cr and VT22 Titanium $\beta$-Alloys under Tension with Different Rates
}

\author{
P. E. Markovsky, V. I. Bondarchuk, O. V. Shepotinnyk, \\ and I. M. Gavrysh \\ G.V. Kurdyumov Institute for Metal Physics, N.A.S. of Ukraine, \\ 36 Academician Vernadsky Blvd., \\ UA-03680 Kyiv, Ukraine
}

Taking two metastable $\beta$-titanium alloys VT22 (Ti-5 (\% wt.) Al-5V-5Mo$1 \mathrm{Fe}-1 \mathrm{Cr}$ ) and $\mathrm{Ti}-3 \mathrm{Al}-4.5 \mathrm{Fe}-7.2 \mathrm{Cr}$ as program materials, the influence of $\beta$ grain size, phase composition, and strain rate (in the range of $3.20 \cdot 10^{-5}$ up to $1.81 \cdot 10^{-1}$ ) on alloys' mechanical behaviour is investigated. The mechanical behaviour of both alloys in as-quenched single-phase $\beta$-state is similar to another metastable $\beta$-alloy TIMETAL-LCB: ductility and tensile toughness are monotonously decreased with strain rate. Ageing causes increase in strength and decrease in ductility, whereas the drop of the latter is the most pronounced in both the coarse-grained VT22 alloy and the $\mathrm{Ti}-3 \mathrm{Al}-4.5 \mathrm{Fe}-7.2 \mathrm{Cr}$ one regardless of grain size. As suggested, the reason of this effect is the formation of thin layers enriched by $\beta$-stabilizing elements located close to grain-boundary $\alpha$-phase. Taking into account drastic embrittlement of Ti$3 \mathrm{Al}-4.5 \mathrm{Fe}-7.2 \mathrm{Cr}$ alloy, which contains only $\beta$-eutectoid alloying elements, this enrichment can lead to the precipitation of intermetallics.

Key words: titanium alloys, mechanical properties, strain rate, tensile toughness, rapid heat treatment.

На прикладі двох промислових титанових стопів метастабільного $\beta$-класу BT22 (Ti-5 (\% мас.) $\mathrm{Al}-5 \mathrm{~V}-5 \mathrm{Mo}-1 \mathrm{Fe}-1 \mathrm{Cr}$ ) та $\mathrm{Ti}-3 \mathrm{Al}-4,5 \mathrm{Fe}-7,2 \mathrm{Cr}$ було

Corresponding author: Pavlo Evgenovych Markovsky

E-mail:pmark@imp.kiev.ua

Please cite this article as: P. E. Markovsky, V. I. Bondarchuk, O. V. Shepotinnyk, and I. M. Gavrysh, Influence of Phase Composition and Microstructure on Mechanical Behaviour of the Metastable $\mathrm{Ti}-3 \mathrm{Al}-4.5 \mathrm{Fe}-7.2 \mathrm{Cr}$ and VT22 Titanium $\beta$-Alloys under Tension with Different Rates, Metallofiz. Noveishie Tekhnol., 38, No. 7: 935-952 (2016), DOI: 10.15407/mfint.38.07.0935. 
вивчено вплив розміру $\beta$-зерен, фазового складу та швидкости деформації на розтяг (у діяпазоні від $3,20 \cdot 10^{-5}$ до $1,81 \cdot 10^{-1}$ ) на їхню механічну поведінку. Механічна поведінка обох стопів, загартованих на однофазний метастабільний $\beta$-стан, є аналогічною до іншого титанового $\beta$-стопу TIMETALLCB: характеристики пластичности та в'язкости руйнування монотонно зменшуються з ростом швидкости деформації. Наступне старіння приводить до росту характеристик міцности та зниження пластичности, причому падіння показників останньої є найбільшим у стопу ВТ22 з грубим зерном та у стопу $\mathrm{Ti}-3 \mathrm{Al}-4,5 \mathrm{Fe}-7,2 \mathrm{Cr}$ незалежно від розміру зерна. Запропоновано висновок про те, що причиною цього є формування тонких шарів, збагачених $\beta$-стабілізувальними елементами, які утворюються безпосередньо біля $\alpha$-пластин, що покривають межі $\beta$-зерен. Із врахуванням критичного окрихчування стопу $\mathrm{Ti}-3 \mathrm{Al}-4,5 \mathrm{Fe}-7,2 \mathrm{Cr}$, який вміщує виключно $\beta$-стабілізувальні легувальні елементи евтектоїдного типу, висловлено припущення про те, що подібне збагачення може приводити до локального утворення інтерметалідів.

Ключові слова: стопи титану, механічні властивості, швидкість деформації, ударна в’язкість при розтягуванні, швидкісне термооброблення.

На примере двух промышленных титановых сплавов метастабильного $\beta$ класса ВТ22 (Ti-5 (\% мас.) $\mathrm{Al}-5 \mathrm{~V}-5 \mathrm{Mo}-1 \mathrm{Fe}-1 \mathrm{Cr}$ ) и $\mathrm{Ti}-3 \mathrm{Al}-4,5 \mathrm{Fe}-7,2 \mathrm{Cr}$ было изучено влияние размера $\beta$-зёрен, фазового состава и скорости деформации растяжением (в диапазоне от $3,20 \cdot 10^{-5}$ до $1,81 \cdot 10^{-1}$ ) на их механическое поведение. Механическое поведение обоих сплавов, закалённых на однофазное метастабильное $\beta$-состояние, является аналогичным поведению другого титанового $\beta$-сплава TIMETAL-LCB: характеристики пластичности и вязкости разрушения монотонно снижаются с ростом скорости деформации. Последующее старение приводит к росту характеристик прочности и снижению пластичности, причём падение показателей последней является наибольшим у сплава ВТ22 с крупным зерном, а у сплава $\mathrm{Ti}-3 \mathrm{Al}-4,5 \mathrm{Fe}-7,2 \mathrm{Cr}$ не зависит от размера зерна. Предложен вывод о том, что причиной этого является формирование тонких слоёв, обогащённых $\beta$-стабилизирующими элементами, которые образуются непосредственно возле $\alpha$-пластин, покрывающих границы $\beta$-зёрен. С учётом критического охрупчивания сплава $\mathrm{Ti}-3 \mathrm{Al}-4,5 \mathrm{Fe}-7,2 \mathrm{Cr}$, который содержит исключительно $\beta$-стабилизирующие легирующие элементы эвтектоидного типа, было высказано предположение о том, что подобное обогащение может приводить к локальному образованию интерметаллидов.

Ключевые слова: сплавы титана, механические свойства, скорость деформации, ударная вязкость при растяжении, скоростная термообработка.

(Received June 13, 2016; in final version, July 14, 2016)

\section{INTRODUCTION}

Titanium alloys are very important and the most promising structural materials for many applications in the field of new technique manufac- 
turing, when high specific strength is the most critical parameter [1, 2]. Advantages of titanium alloys over other metallic materials become more evident when these alloys are employed in high-strength condition. Tensile strength not lower than $1500 \mathrm{MPa}$, well balanced with other mechanical characteristics, is more required today. However, conventional methods of treatment of metallic materials cannot ensure such balance of properties. For commercial titanium alloys, it was shown that only special so-called Rapid Heat Treatment (RHT) can create specific microstructural conditions, which are characterized by fine $\beta$-grains (of few micrometres) with ultra-fine intragrain $\alpha+\beta$ mixture (in nanometres' scale), providing a unique combination of high strength with acceptable ductility, fatigue strength and other essential properties [3-5].

The mechanical behaviour of structural materials at different loading rates, especially under high-rate deformation, is also important for various practical applications. There are a few publications related to this problem. Most attention was paid to the study of mechanical behaviour of single-phase beta condition on tension with different rates [6-8]. For the two-phase structural condition, the first work was done with TIMETAL-LCB alloy [9] and it was found that ageing of finegrained microstructure allowed to achieve in this alloy ultimate tensile strength of $1500 \mathrm{MPa}$ with total elongation of $3-5 \%$, whereas in coarse-grained condition the alloy had null elongation at similar strength level at all strain rates applied. Increased strength after ageing led to reduced energy expended on deformation and fracture of the material, especially if compared with the initial as-quenched state with high ductility, so the material toughness is more determined by its ductility than by strength. In the present study, we investigated two others titanium alloys of the same metastable $\beta$-type, namely VT2 2 and $\mathrm{Ti}-3 \mathrm{Al}-4.5 \mathrm{Fe}-7.2 \mathrm{Cr}$. These alloys also were taken in two principally different microstructural conditions: fine- and coarse-grained, as well as single-phase $\beta$, and two-phase $\alpha+\beta$ conditions. Obtained results were compared with earlier ones for TIMETAL-LCB.

\section{MATERIALS AND EXPERIMENTAL PROCEDURES}

VT22 (Ti-5 (\% wt.) $\mathrm{Al}-5 \mathrm{~V}-5 \mathrm{Mo}-1 \mathrm{Cr}-1 \mathrm{Fe})$ and $\mathrm{Ti}-3 \mathrm{Al}-4.5 \mathrm{Fe}-7.2 \mathrm{Cr}$ both as $\varnothing 20 \mathrm{~mm}$ rod were taken as program materials. Both rods were cut into specimens $200 \mathrm{~mm}$ long for subsequent heat treatments and tests. Each alloy was subjected to solid-solution acting treatments aimed on the formation of a single-phase $\beta$-state that was performed in two ways: i) 30 -minute furnace exposure at $900^{\circ} \mathrm{C}$ for forming coarsegrained (CG) condition (Fig. 1, $a$ and $c$ ), and ii) Rapid Heating with rate of $20^{\circ} \mathrm{C} / \mathrm{s}$ up to $920^{\circ} \mathrm{C}$ without exposure at peak temperature for forming fine-grained (FG) condition (Fig. 1, $b$ and $d$ ). In both cases, heating 
was followed by water quenching to fix metastable $\beta$-phase at room temperature. Some of as-quenched specimens were subjected to final ageing by regimes described in the previous works [5, 10] (see Table 1).

Taking into account the data previously obtained for TIMETAL-LCB

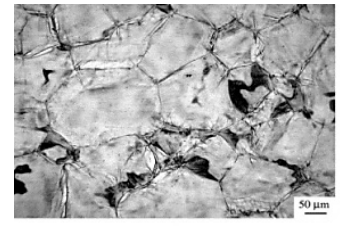

$a$

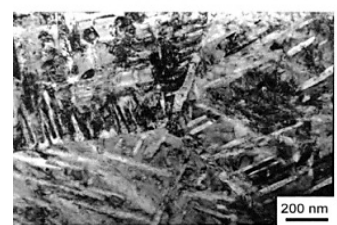

$d$

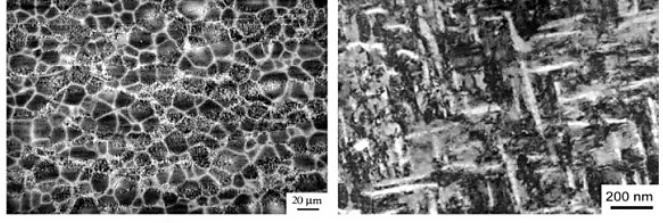

b

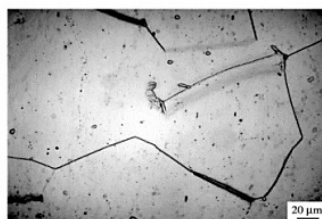

$e$

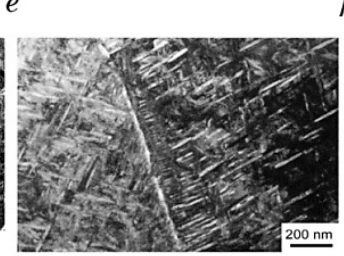

h

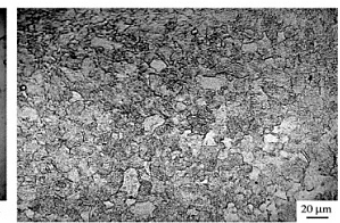

$f$
.

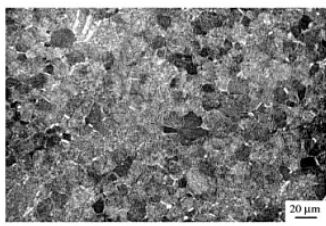

g

Fig. 1. Microstructure of the VT22 $(a-d)$ and Ti-3Al-4.5Fe-7.2Cr $(e-h)$ alloys in CG $(a, e), \mathrm{FG}(b, f)$, and FG + aged conditions $(c, d, g, h) ; \mathrm{LM}(a-c, e-g)$, bright field images $(a, c, e-g)$, dark field image $(b), \operatorname{TEM}(d, h)$.

TABLE 1. Heat treatments of the VT22 and Ti-3Al-4.5Fe-7.2Cr alloys.

\begin{tabular}{|c|c|c|c|c|}
\hline \multicolumn{2}{|c|}{$\begin{array}{l}\text { Microstructural } \\
\text { condition }\end{array}$} & \multirow{2}{*}{$\begin{array}{c}\text { Condition/Ageing } \\
\text { temperature and } \\
\text { time }\end{array}$} & \multicolumn{2}{|c|}{$\begin{array}{l}\text { Size }(\text { thickness } \times \text { length) of } \\
\text { microstructural elements }\end{array}$} \\
\hline No. & Type & & $\beta$-grain, $\mu \mathrm{m}$ & $\alpha$-particles, $\mathrm{nm}$ \\
\hline \multicolumn{5}{|c|}{ VT22 } \\
\hline 1 & Coarse-grained & As-quenched & $210 \pm 30$ & - \\
\hline 2 & Fing mroinod & As-quenched & $20 \pm 5.8$ & - \\
\hline 3 & Fine-gralned & $+\operatorname{aged} 640^{\circ} \mathrm{C}, 8 \mathrm{~h}$ & $20 \pm 5.8$ & $(30 \pm 5.2) \times(500 \pm 35)$ \\
\hline \multicolumn{5}{|c|}{$\mathrm{Ti}-3 \mathrm{Al}-4.5 \mathrm{Fe}-7.2 \mathrm{Cr}$} \\
\hline 4 & Coarse-grained & As-quenched & $200 \pm 40$ & - \\
\hline 5 & & As-quenched & $18 \pm 3.9$ & - \\
\hline 6 & Fine-grained & + aged $550^{\circ} \mathrm{C}, 6 \mathrm{~h}$ & $18 \pm 3.9$ & $(20 \pm 2.4) \times(280 \pm 22)$ \\
\hline
\end{tabular}


alloy [9], we studied aged conditions for FG conditions only, as the CG showed extremely low ductility.

The samples were characterized with light microscopy (LM), transmission electron microscopy (TEM), X-Ray diffraction analysis. The tensile specimens with gage of $4 \mathrm{~mm}$ diameter and $25 \mathrm{~mm}$ length were machined and tested in accordance with the ASTM E8M standard. Tensile tests were performed at INSTRON-3376 unit with strain rates varying from $3.20 \cdot 10^{-5}$ to $1.81 \cdot 10^{-1}$. Fracture surfaces of tested specimens, as well as local chemical composition were examined with a scanning electron microscope (SEM) equipped with INCA Energy SEM.

\section{EXPERIMENTAL RESULTS AND DISCUSSION}

\subsection{Strain Curves}

\subsubsection{VT22}

Typical engineering tensile stress-strain curves for all studied conditions, namely CG, FG and FG + aged, are presented in Fig. 2.

Comparing the results in Fig. 2, one can note the following features. First of all, the single-phase $\beta$-conditions of VT22 alloy are rather ductile: even at the highest strain rates, both fine-grained and coarsegrained material has acceptable elongation (Fig. 2, $a, b$ ). Increase in strain rate resulted in simultaneous raise of strength and decrease in ductility, that is common for the titanium alloys of this type [6-9]. A comparison of FG and CG conditions shows that finer grains caused somewhat higher ductility and strength for the same strain rates. The $\alpha$-phase particles precipitated on ageing caused significant increase in strength (from 900-1000 MPa up to 1300-1390 MPa, depending on strain rate), but elongation dropped drastically (Fig. 2, c).

\subsection{2. $\mathrm{Ti}-3 \mathrm{Al}-4.5 \mathrm{Fe}-7.2 \mathrm{Cr}$}

Typical engineering stress-strain curves for this alloy are shown in Fig. 3. First of all, it should be mentioned that this alloy was designed as a low cost material for special applications (material for production of supporting equipment for elderly population care), and originally it was not assigned for high-level mechanical properties [11].

Contrary to VT22, in this alloy, the contribution of localized deformation (strain after necking) into total plastic strain is bigger as compared to uniform deformation (prior to necking), and the fraction of localized deformation is close to $100 \%$ at strain rates of about $10^{-3}$. Besides, a comparison with the VT22 allows to note that in as-quenched (single metastable $\beta$-phase) conditions the strength is higher, but elon- 


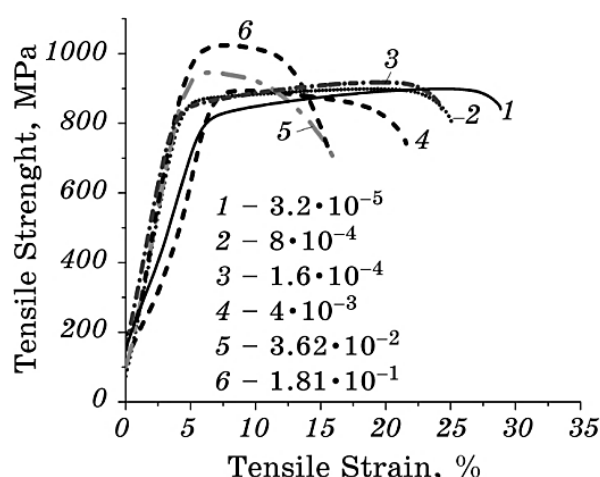

a

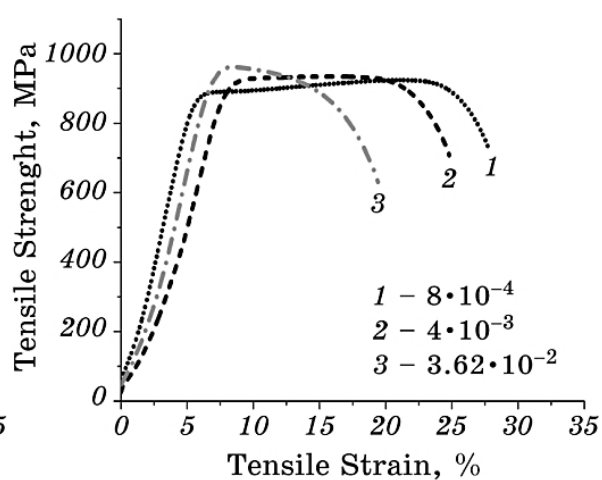

$b$

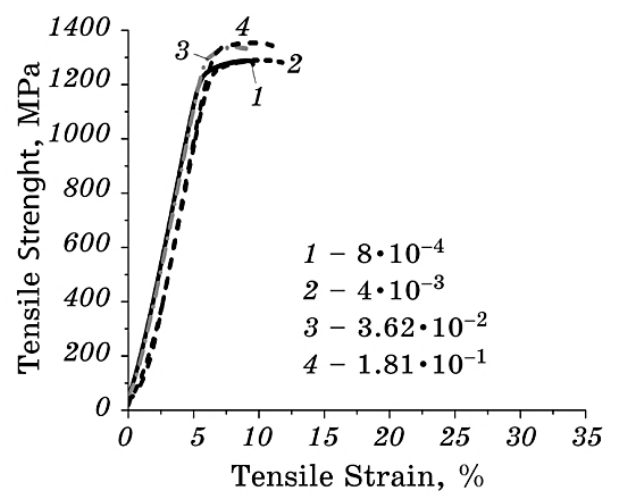

$c$

Fig. 2. Typical engineering stress-strain curves of VT22 alloy in conditions: $\mathrm{CG}(a), \mathrm{FG}(b)$, and $\mathrm{FG}+$ aged $(c)$ at $640^{\circ} \mathrm{C}, 8 \mathrm{~h}$.

gation is noticeably lower (compare Figs. 3, $a, b$ with Figs. 2, $a, b$ ).

The most substantial differences are observed in the aged condition: at all strain rates, the material was absolutely brittle (Fig. 3, c). Obviously, this can be associated with somewhat larger $\beta$-grains in FG condition (approximately $20 \mu \mathrm{m}$ ), since in the previous work this alloy with finer grains (less than $10 \mu \mathrm{m}$ ) showed acceptable ductility after similar ageing [10].

\subsection{Tensile Toughness}

As shown in the previous study [9], the approach based on the analysis of tensile toughness (that corresponds to the work expended on the deformation to fracture measured as the area under the engineering stress-strain curves or deformation energy $\left(U_{\mathrm{T}}\right)$ in [12]), allows to compare the mechanical behaviour of different alloys in relation with 


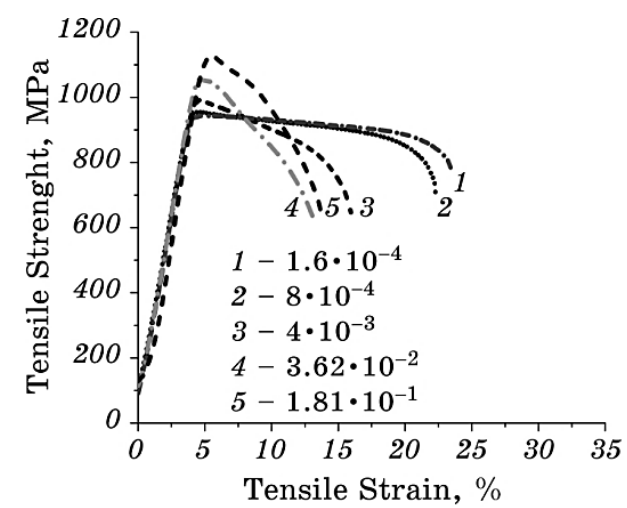

$a$

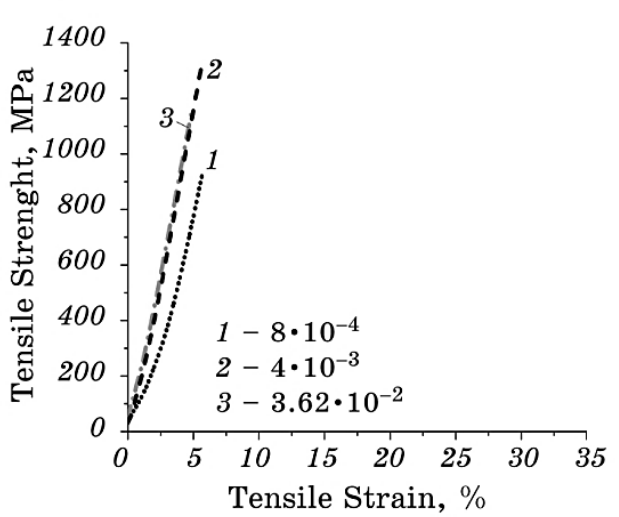

$c$

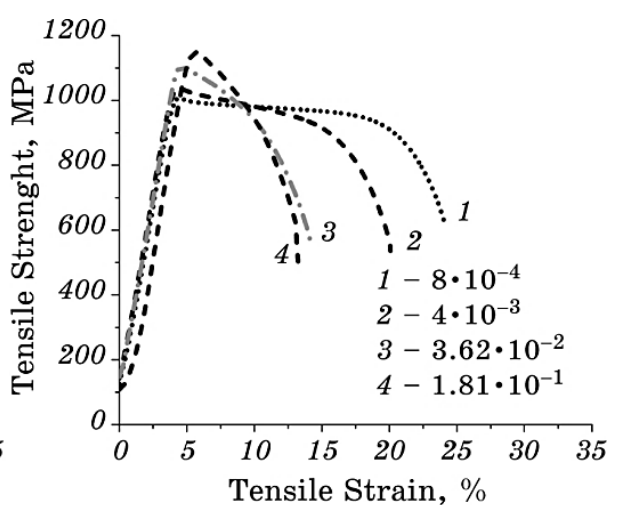

b

Fig. 3. Typical engineering tensile stress-strain curves of $\mathrm{Ti}-3 \mathrm{Al}-4.5 \mathrm{Fe}-$ 7.2Cr alloy in conditions: $\mathrm{CG}(a), \mathrm{FG}(b)$ and $\mathrm{FG}+\operatorname{aged}(c)$ at $550^{\circ} \mathrm{C}, 6 \mathrm{~h}$.

their microstructure and phase composition. The data calculated for VT22 in different microstructural states are presented in Fig. 4.

For both CG and FG single-phase $\beta$-states, the elevation of strain rate caused a decrease of uniform deformation contribution and an increase of localized deformation contribution into the total value of tensile toughness (Fig. 4, $a, b$ ). In the aged two-phase condition, these contributions did not change significantly with strain rate (Fig. $4, c)$. This difference in the mechanical behaviour can be attributed mainly to the uniform plastic deformation prior to necking: in the former case (single-phase beta condition), it gradually decreases with strain rate, whereas in the latter case strain rate has no noticeable influence on all components (please note very low plastic deformation after necking). A comparison of these data with the previous results obtained for TIMETAL-LCB after similar heat treatments $[8,9]$ allows to state that 


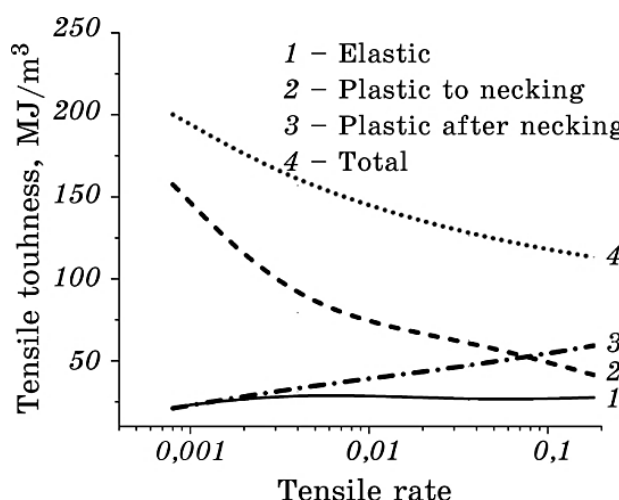

$a$

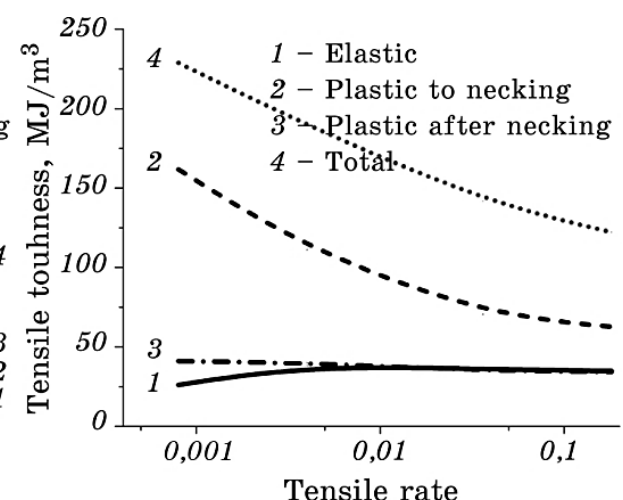

$b$

Fig. 4. Tensile toughness of VT22 alloy in CG (a), FG (b) and FG + aged (c) at $640^{\circ} \mathrm{C}, 8 \mathrm{~h}$ conditions.

these parameters are rather close; nevertheless, in VT22 alloy, the contribution of localized deformation (after necking) is noticeably lower.

$\mathrm{Ti}-3 \mathrm{Al}-4.5 \mathrm{Fe}-7.2 \mathrm{Cr}$ alloy in the single-phase $\beta$-conditions showed a similar behaviour as the above mentioned VT22 and earlier studied TIMETAL-LCB [8, 9]: the contribution of uniform deformation gradually decreased with strain rate (Fig. 5).

Other features are same: elastic and uniform plastic elongations slightly increase with strain rate, and the total tensile toughness in FG condition is higher as compared with CG one. In FG + aged two-phase state, the tensile toughness at all strain rates was determined solely by the elastic component due to drastic embrittlement (Fig. 3,c), and it

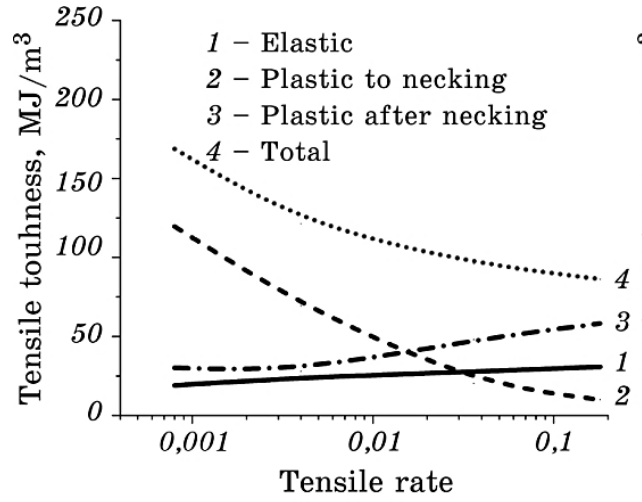

$a$

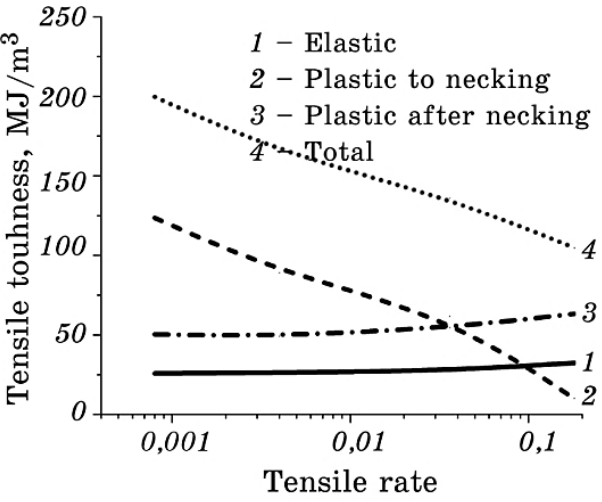

$b$

Fig. 5. Tensile toughness of $\mathrm{Ti}-3 \mathrm{Al}-4.5 \mathrm{Fe}-7.2 \mathrm{Cr}$ alloy in $\mathrm{CG}(a)$ and $\mathrm{FG}(b)$ conditions. 
$\operatorname{did}$ not exceed $20-25 \mathrm{MJ} / \mathrm{m}^{3}$.

\subsection{Fractography}

\subsubsection{VT22}

For better understanding of the deformation behaviour and fracture features, we studied the fracture surfaces of the tensile specimens, typical examples of which are shown in Figs. 6-8. Firstly, it should be noted that in CG as-quenched condition some traces of large grain boundaries are well seen on the fracture surface (Fig. 6, $a$ ). At the same time, in FG material tensioned at low strain rate, no microstructural features were observed on the fracture surface (Fig. 6,b). Nevertheless, at the macrolevel, both materials have entirely ductile fracture surfaces with fine dimples, and in FG material, it is more uniform throughout the whole fracture surface. The size of these dimples cannot be attributed to the grain size, so the accumulation of deformation

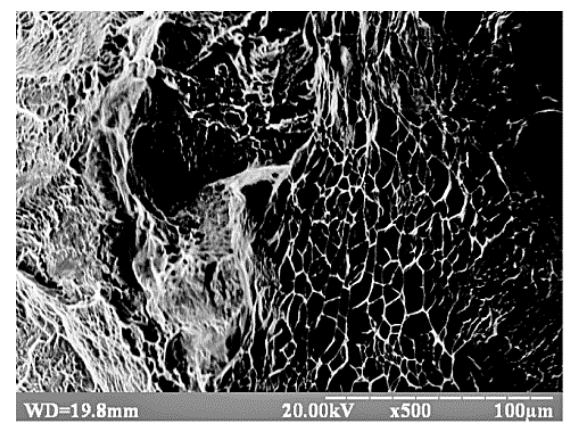

$a$

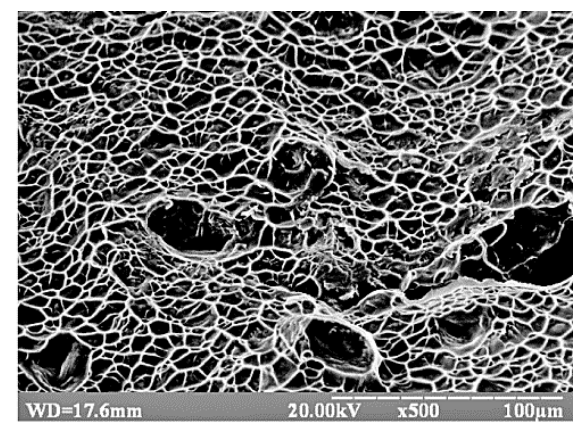

$b$

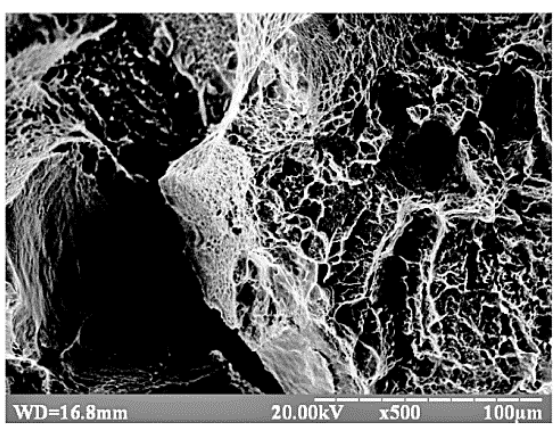

Fig. 6. Typical fracture surfaces of VT22 alloy in CG (a), FG $(b)$ and FG + aged (c) conditions tested with strain rate of $8 \cdot 10^{-4}$ (SEM). 
defects leads to the situation when fracture occurs at the subgrain level. After the ageing, there are more traces of grain boundaries in FG material, and the secondary cracks along grain boundaries appear (Fig. $6, c)$. This allows suggesting that the grain interiors became stronger than the grain boundaries; nevertheless, at the microlevel fracture surface is rather ductile, and dimples are still observed.

The increase in strain rate up to $3.62 \cdot 10^{-2}$ did not change the type of fracture in both CG and FG states (Fig. 7, $a, b$ ). In CG condition, some traces of grain boundaries are observed in the centre of the sample (initial fracture), whereas these traces were absent on the perimeter (final rupture). The fracture surface of the material after strengthening (FG + ageing) remains the same as at lower strain rates.

At the highest strain rate of $1.81 \cdot 10^{-1}$, the general character of fracture remains the same (compare Figs. 8 and 7). It is worthwhile to note the formation of some facets of brittle fracture (Fig. 7, $a$ ) in CG material, whereas it is not typical for this ductile material. In the FG singlephase $\beta$-material, the difference between zones of fracture initiation and final rupture is more pronounced as compared to lower strain rate

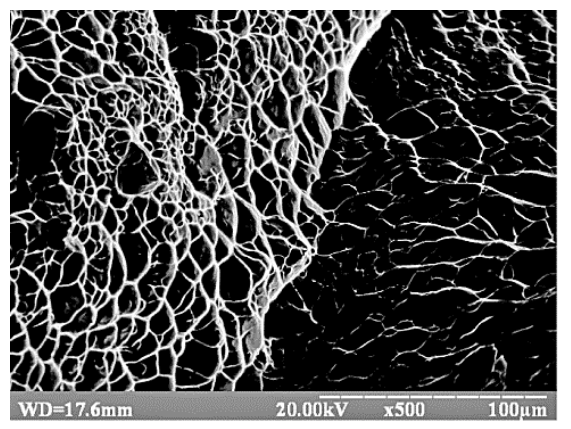

$a$

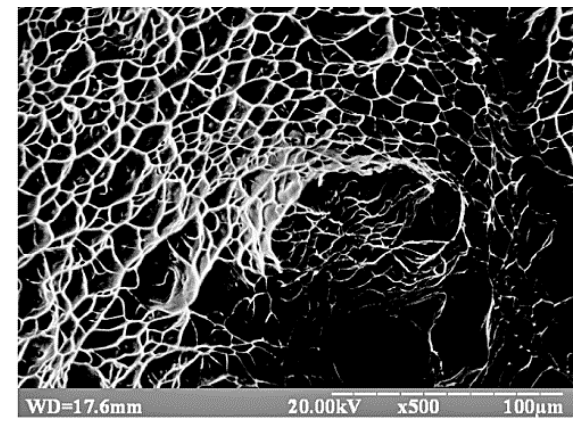

$b$

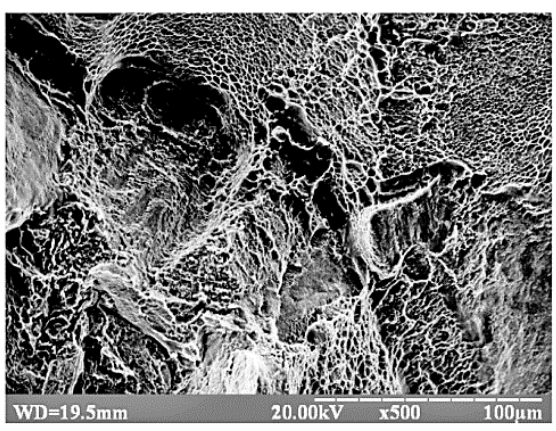

Fig. 7. Typical fracture surfaces of VT22 alloy in CG (a), FG (b) and FG + aged (c) conditions tested with strain rate of $3.62 \cdot 10^{-2}$ (SEM). 
of $3.62 \cdot 10^{-2}$. Nevertheless, in both zones, ductile fracture is observed. In age-hardened FG condition, the nature of fracture surface remains unchanged: fracture (including secondary cracks) along grain boundaries and dimples at the microlevel (Fig. 8,a).

Thus, the analysis of fracture surfaces suggests that grain boundaries play a significant role in the processes of deformation, crack nucleation and propagation, as well as final fracture of the material in CG single-phase $\beta$-condition at all strain rates. The grain boundaries play similar role in the deformation and fracture in FG condition with twophase (aged) microstructure. In the FG single-phase $\beta$-material, the impact of some grain boundaries (with specific crystallographic orientation [8]) was observed only at higher strain rates.

Having in mind the goal to estimate the relationship between microstructure elements and localization of crack nucleation and propagation, we studied chemical composition of different zones (ductile and brittle, see Figs. 9, $a, b$ respectively) on the fracture surfaces. The average values (at least 9 measurements) are shown in Table 2.

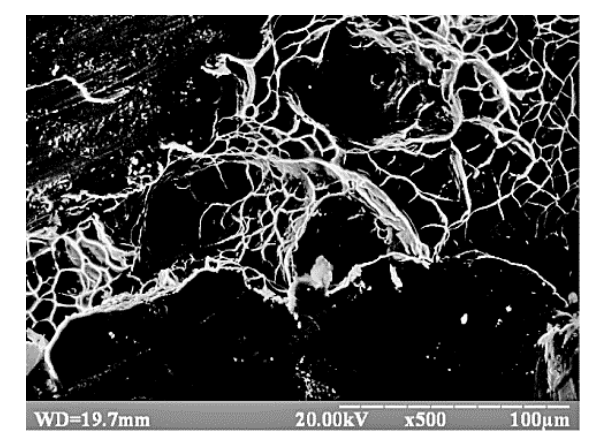

$a$

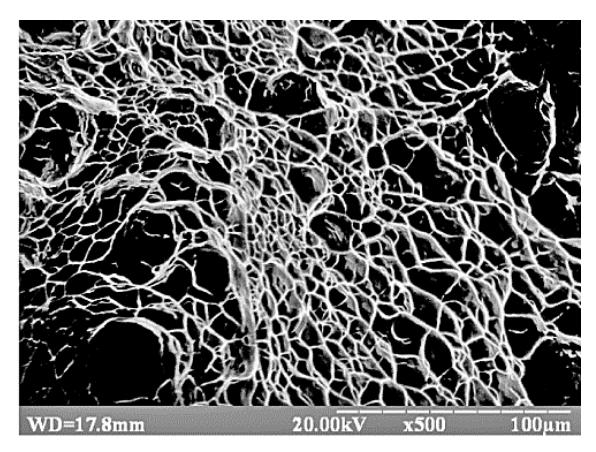

$b$

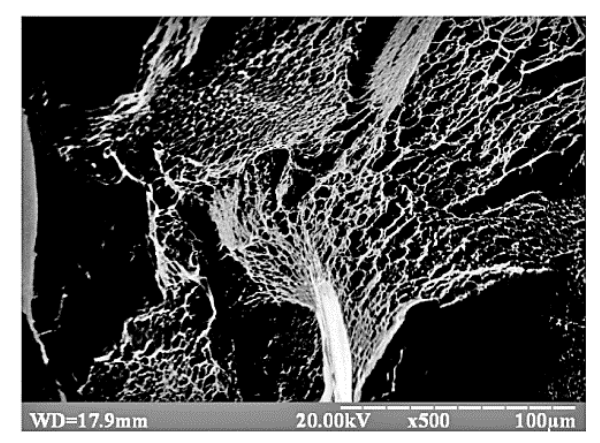

$c$

Fig. 8. Typical fracture surfaces of VT22 alloy in CG (a), FG (b) and FG + aged (c) conditions tested with strain rate of $1.81 \cdot 10^{-1}$ (SEM). 


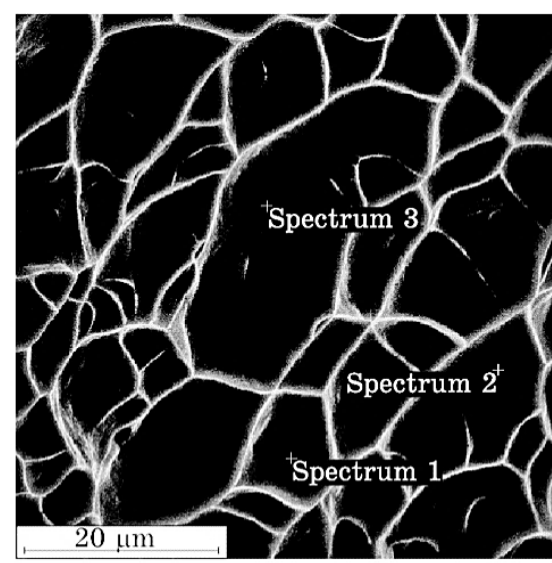

$a$

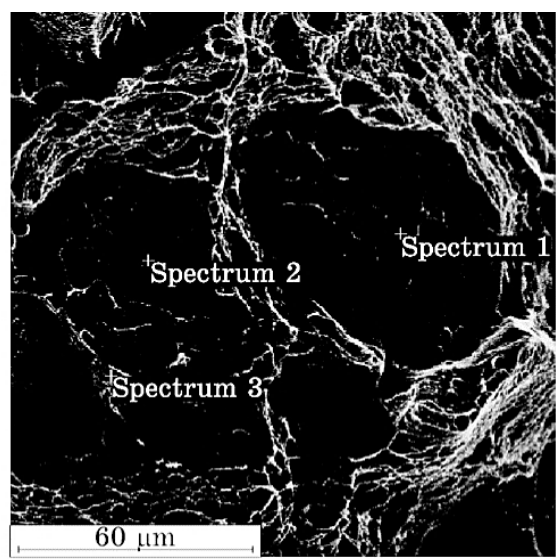

$b$

Fig. 9. Examples of analysed sites on fracture surface of VT22 alloy in FG (a) and $\mathrm{FG}+$ aged $(b)\left(640^{\circ} \mathrm{C}, 8 \mathrm{~h}\right)$ conditions. Ductile $(a)$ and brittle $(b)$ areas (SEM).

As can be seen, the chemical composition in the ductile zone (No. 1, 2 , and 4 ) is very close to the total content of alloying elements in the alloy. At the same time, the zones of the brittle fracture (No. 3) are depleted of all alloying elements, except vanadium. To clarify this, we studied the distribution of alloying elements across grain boundaries in FG + ageing state, using polished microsections. The results are summarized in Fig. 10, $a$, and the data recalculated by molybdenum equivalent (integral content of $\beta$-alloying elements [2]) are presented

TABLE 2. Local composition of $\mathrm{VT} 22$ and $\mathrm{Ti}-3 \mathrm{Al}-4.5 \mathrm{Fe}-7.2 \mathrm{Cr}$ alloys on different areas of fracture surface.

\begin{tabular}{|c|c|c|c|c|c|c|c|c|}
\hline \multirow{2}{*}{ No. } & \multirow{2}{*}{ Condition } & \multirow{2}{*}{ Location } & \multicolumn{6}{|c|}{ Composition, \% wt. } \\
\hline & & & $\mathrm{Al}$ & Mo & $\mathrm{Fe}$ & $\mathrm{Cr}$ & $\mathrm{V}$ & $\mathrm{Ti}$ \\
\hline \multicolumn{9}{|c|}{ VT22 (Ti-5Al-5V-5Mo-1Cr-1Fe) } \\
\hline 1 & FG, WQ & Ductile & 5.88 & 5.50 & 1.13 & 1.08 & 5.02 & \multirow{4}{*}{ Balance } \\
\hline 2 & $\mathrm{FG}, \mathrm{WQ}+640^{\circ} \mathrm{C}$, & Ductile & 6.45 & 5.88 & 1.01 & 0.93 & 4.78 & \\
\hline 3 & & Brittle & 3.19 & 4.74 & 0.99 & 0.66 & 5.55 & \\
\hline 4 & CG, WQ & Ductile & 5.97 & 5.68 & 1.09 & 1.03 & 4.82 & \\
\hline \multicolumn{9}{|c|}{$\mathrm{Ti}-3 \mathrm{Al}-4.5 \mathrm{Fe}-7.2 \mathrm{Cr}$} \\
\hline 5 & FG, WQ & Ductile & 2.35 & - & 4.1 & 6.72 & - & \multirow[b]{2}{*}{ Balance } \\
\hline 6 & $\begin{array}{c}\mathrm{FG}, \mathrm{WQ}+560^{\circ} \mathrm{C}, \\
6 \mathrm{~h}\end{array}$ & Brittle & 3.20 & - & 4.25 & 7.32 & - & \\
\hline
\end{tabular}


in Fig. 10, $b$.

An analysis of the data in Fig. 10, $a$ and their comparison with Table 2 allow to suggest that the chemical composition in brittle zones (line No. 3 in Table 2) quite well corresponds (except chromium) to the regions around the grain boundary $\alpha$-phase layers (indicated in Fig. 10, $a$ by arrow). As seen in Fig. 10, $b$, there are narrow (about $10 \mu \mathrm{m}$ ) zones around $\beta$-grain boundaries; in these zones, the content of alloying elements changes from 8.2 to $9.0-9.2 \%$ wt., and they (not grainboundary $\alpha$-phase itself!) can play the role of 'weak links' where frac-

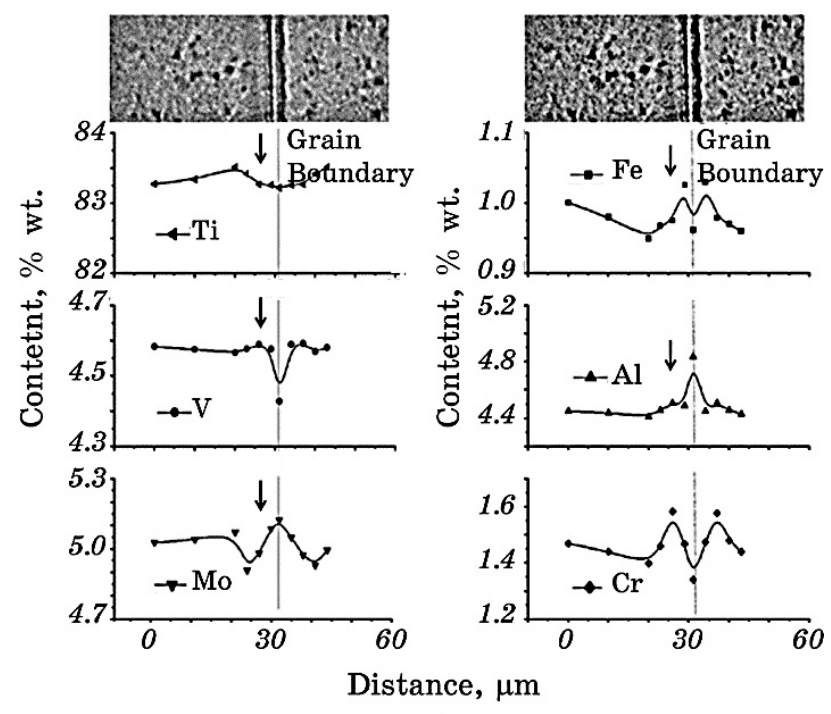

$a$

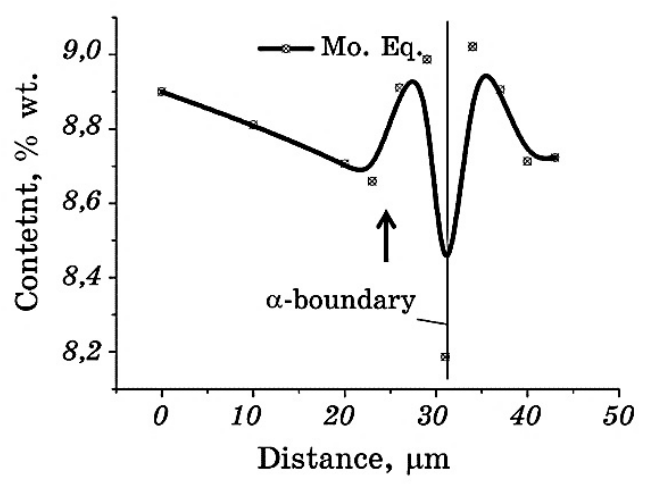

$b$

Fig. 10. Alloying element distribution through the grain boundary of FG VT22 aged at $640^{\circ} \mathrm{C}$ for $8 \mathrm{~h}$ : alloying elements distribution (a), integral distribution of $\beta$-alloying elements $(b)$ (recalculated by Molybdenum Equivalent according to [2]). Arrows mark possible sites of brittle fracture. 
ture starts.

It should be noted that the ageing of this alloy in CG condition caused similar changes in the alloying element distributions, but the grain boundary $\alpha$-layers and zones depleted of $\beta$-stabilizing elements were much thicker.

\subsection{2. $\mathrm{Ti}-3 \mathrm{Al}-4.5 \mathrm{Fe}-7.2 \mathrm{Cr}$}

Similar study of fracture surfaces was undertaken for $\mathrm{Ti}-3 \mathrm{Al}-4.5 \mathrm{Fe}-$ $7.2 \mathrm{Cr}$ alloy. Typical examples of fracture surfaces are presented in Figs. 11-13. At first, it should be noted that on the fracture surfaces of the material in CG as-quenched condition some traces of grain boundaries and elements of relief peculiar to titanium alloys with coarse $\alpha+\beta$ lamellae colonies (Fig. 11, $a$, marked by arrow) were observed. At the same time, in FG single-phase material, the traces of grain boundaries were not revealed (Fig. 11, b). Nevertheless, at the microlevel, both materials have entirely ductile fracture with fine dimples (Fig. 11, $a, b$ ). The size of these dimples cannot be associated

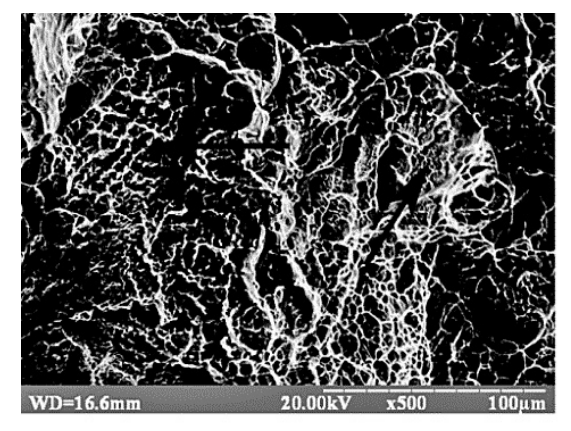

a

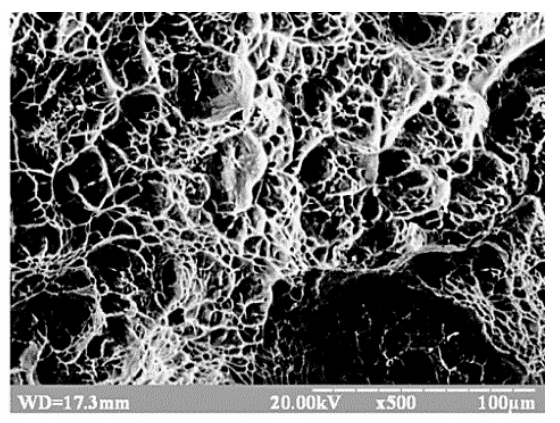

$b$

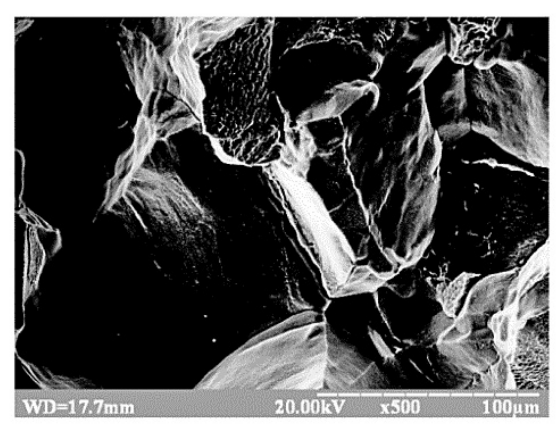

Fig. 11. Typical fracture surfaces of $\mathrm{Ti}-3 \mathrm{Al}-4.5 \mathrm{Fe}-7.2 \mathrm{Cr}$ alloy in $\mathrm{CG}(a)$, FG (b) and FG + aged (c) conditions tested with strain rate of $8 \cdot 10^{-4}$ (SEM). 
with the grain size, so one can assume that the accumulation of deformation defects occurred at a smaller, i.e. subgrain level.

Ageing of FG material led to the appearance of grain boundary trac-

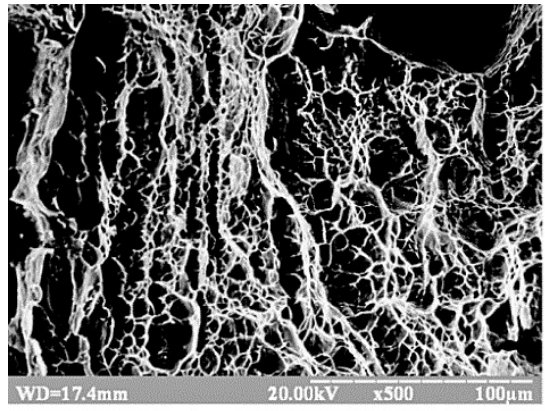

$a$

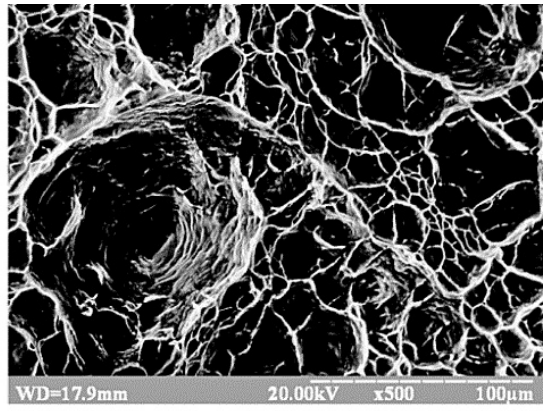

$b$

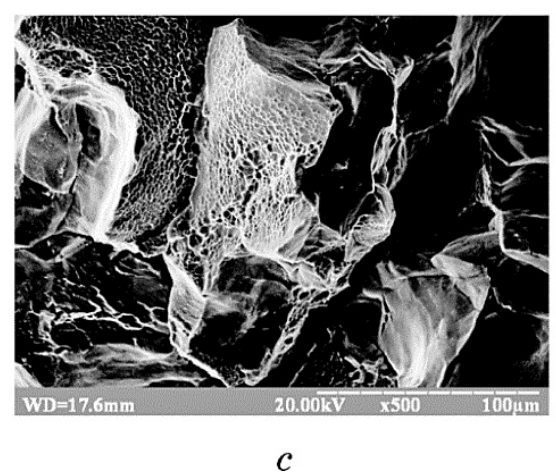

Fig. 12. Typical fracture surfaces of $\mathrm{Ti}-3 \mathrm{Al}-4.5 \mathrm{Fe}-7.2 \mathrm{Cr}$ alloy in $\mathrm{CG}(a), \mathrm{FG}$ $(b)$ and $\mathrm{FG}+$ aged $(c)$ conditions tested with strain rate of $3.62 \cdot 10^{-2}$ (SEM).

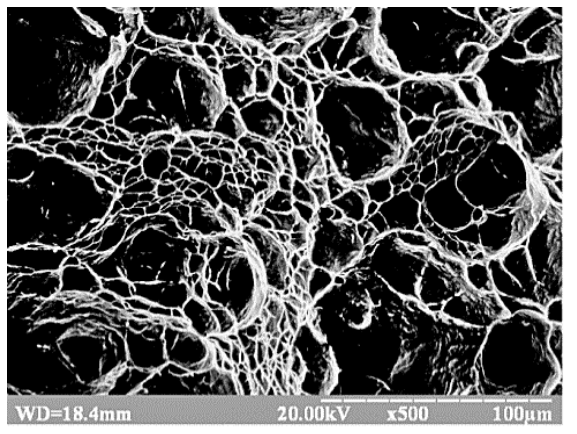

$a$

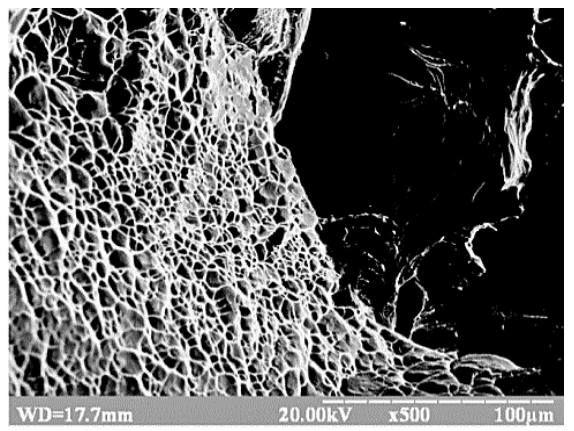

$b$

Fig. 13. Typical fracture surfaces of $\mathrm{Ti}-3 \mathrm{Al}-4.5 \mathrm{Fe}-7.2 \mathrm{Cr}$ alloy in $\mathrm{CG}(a)$ and FG $(b)$ conditions tested with strain rate of $1.81 \cdot 10^{-1}$ (SEM). 
es and secondary cracking along grain boundaries (Fig. 11, c). This allows suggesting that the grain interiors became appreciably stronger than the grain boundaries. Nevertheless, at the microlevel, brittle cleavage is mainly observed, and the number of ductile dimples is very low (Fig. 11,c).

With strain rate increase (up to $3.62 \cdot 10^{-2}$ ), the general character of fracture surfaces in CG single-phase material did not change: the traces of grain boundaries and ductile dimples are fairly seen (Fig. 12,a). In FG single-phase material, a sharp transition between the zones of initial fracture and fast final rupture was observed, but in both zones fracture was ductile (Fig. 12,b). Brittle cleavage facets were mainly observed in the aged FG state as well, but ductile dimples were more often as compared with slower strain rates (compare Figs. 12, $c$ and 11, c). This trend persisted on increasing strain rate up to $1.81 \cdot 10^{-1}$ (Fig. 13).

The analysis of chemical compositions in different fracture zones (Fig. 14) revealed a reverse (contrary VT22) tendency: the zones of brittle fracture were enriched by all alloying elements (Table 2, No. 5 and 6). In the earlier studies of this alloy, after similar heat treatment [10], thin layers enriched by $\beta$-alloying eutectoid elements $\mathrm{Fe}$ and $\mathrm{Cr}$ were revealed near the grain boundary $\alpha$-phase. Despite the fact that $\mathrm{Ti}-\mathrm{Fe}$ and $\mathrm{Ti}-\mathrm{Cr}$ intermetallides were not found in the previous and present studies (that might be explained by their low volume fraction), one cannot exclude their formation leading to detrimental loss of ductility.

Thereby, VT22 alloy, which contains both types of $\beta$-alloying elements (isomorphous Mo and V, eutectoid Fe and $\mathrm{Cr}$ ), showed mechani-

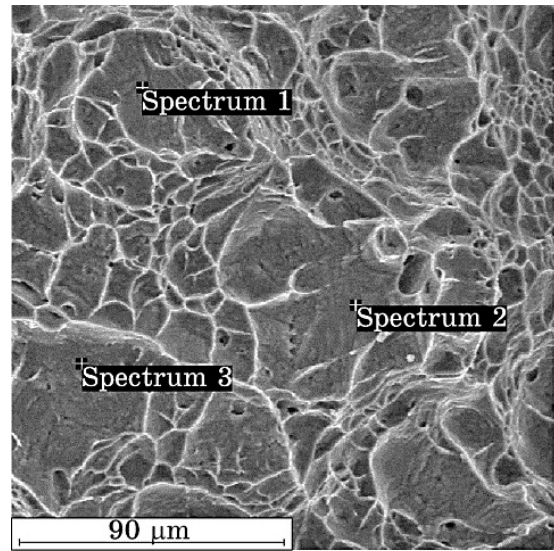

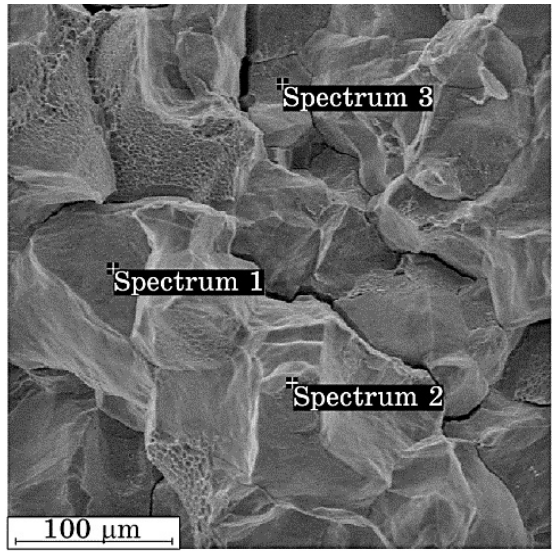

$b$

Fig. 14. Examples of analysed sites in $\mathrm{Ti}-3 \mathrm{Al}-4.5 \mathrm{Fe}-7.2 \mathrm{Cr}$ alloy in $\mathrm{FG}(a)$ and $\mathrm{FG}+$ aged $(b)\left(560^{\circ} \mathrm{C}, 6 \mathrm{~h}\right)$ conditions. Ductile $(a)$ and brittle $(b)$ areas (SEM). 
cal behaviour on tension with different strain rates very similar to the earlier studied TIMETAL-LCB. Quantitative difference between them (in tensile toughness) can be explained by lower integral content of $\beta$ stabilizers in VT22. As for Ti-3Al-4.5Fe-7.2Cr, the absence of $\beta$ isomorphous alloying elements caused the formation of the enriched by $\beta$-eutectoid elements layers adjacent to the grain boundaries, and this, possibly, could cause embrittlement due to formation of intermetallic compounds.

\section{CONCLUSIONS}

1. The mechanical behaviour of VT22 and $\mathrm{Ti}-3 \mathrm{Al}-4.5 \mathrm{Fe}-7.2 \mathrm{Cr}$ alloys in as-quenched single-phase $\beta$-condition is similar to another metastable $\beta$-alloy TIMETAL-LCB: ductility and tensile toughness monotonously decrease with strain rate.

2. The fine-grained microstructures in both alloys had higher balance of mechanical properties at all strain rates applied as compared to the coarse-grained ones.

3. Ageing of as-quenched alloys caused increase in strength and decrease in ductility; the drop of plasticity was most detrimental in the VT22 in coarse-grained condition and in the $\mathrm{Ti}-3 \mathrm{Al}-4.5 \mathrm{Fe}-7.2 \mathrm{Cr}$ regardless of the grain size.

4. The reason of the ductility drop and, as a result, of tensile toughness in aged alloys is the formation of thin layers enriched by $\beta$-stabilizing elements, located close to grain boundary $\alpha$-phase. Taking into account drastic embrittlement of $\mathrm{Ti}-3 \mathrm{Al}-4.5 \mathrm{Fe}-7.2 \mathrm{Cr}$ alloy, which contains only $\beta$-eutectoid alloying elements, this enrichment can lead to the precipitation of intermetallics.

\section{REFERENCES}

1. G. Lutjering and J. C. Williams, Titanium (Berlin-Heidelberg: Springer-Verlag: 2003).

2. P. J. Bania, Beta Titanium Alloys in the 90's (Eds. D. Eylon, R. R. Boyer, and D. A. Koss) (Warrendale, PA: TMS Publications: 1993), p. 3.

3. O. M. Ivasishin, P. E. Markovsky, Yu. V. Matviychuk, and S. L. Semiatin, Metall. Mater. Trans. A, 34, Iss. 1: 147 (2003).

4. O. M. Ivasishin, P. E. Markovsky, S. L. Semiatin, and C. H. Ward, Mat. Sci. Eng. A, 405: Iss. 1-2: 296 (2005).

5. O. M. Ivasishin, P. E. Markovsky, Yu. V. Matviychuk, S. L. Semiatin, C. H. Ward, and S. A. Fox, J. Alloys Compd., 457, Iss. 1-2: 296 (2008).

6. N. Stefansson, I. Weiss, A. J. Hutt et al., Titanium'95: Science and Technology (Eds. P. A. Blenkinsop, W. J. Evans, and H. M. Flower) (Cambridge: The University Press: 1996), vol. 2, p. 980.

7. A. Bhattacharjee, P. Ghosal, A. K. Gogia, S. Bhargava, and S. V. Kamat, 
Mater.Sci.Eng. A, 452-453: 219 (2007).

8. P. E. Markovsky, V. I. Bondarchuk, and Yu. V. Matviychuk, Mater. Sci. Eng. A, 559: 782 (2013).

9. P. E. Markovsky, V. I. Bondarchuk, and O. M. Herasymchuk, Mater. Sci. Eng. A, 645: 150 (2015).

10. P. E. Markovsky and M. Ikeda, Mater. Transactions, 46, No. 7: 1515 (2005).

11. M. Ikeda, S. Komatsu, K. Inoue, H. Shiota, and T. Imose, Mater. Sci. Technol., 16: 605 (2000).

12. Tensile Testing: Handbook (Ed. J. R. Davis) (Materials Park, OH: ASM International: 2004). 